\title{
PENGEMBANGAN MEDIA CHEM PUZZLE PADA MATERI TATA NAMA SENYAWA KELAS X DI SMAN 1 ALALAK
}

\section{The Development of Chem Puzzle Media on Compound Nomenclature Topic in SMAN 1 Alalak}

\author{
Halita*, Herlina Apriani, Novrian Dony \\ Program Studi Pendidikan Kimia Fakultas Keguruan dan Ilmu Pendidikan \\ Universitas Islam Kalimantan (Uniska) Muhammad Arsyad Al Banjari, Banjarmasin \\ email : halitalita171@gmail.com
}

\begin{abstract}
Abstrak. Penelitian ini bertujuan untuk menguji kelayakan chem puzzle sebagai media pembelajaran pada materi tata nama senyawa di SMAN 1 Alalak. Media chem puzzle menjadi bahan media pembelajaran pada materi tata nama senyawa yang mana media ini mempermudah siswa untuk mengingat materi dalam pembelajaran materi tata nama senyawa. Metode penelitian yaitu R \& D (Research and Development) oleh Sugiyono langkah 1 sampai 8. Teknik analisis data yang digunakan yakni deskriptif kuantitatif. Hasil analisis angket validitas media chem puzzle oleh ahli diperoleh rata-rata 93,75 dengan kategori sangat layak. Hasil analisis angket uji pemakaian media chem puzzle pada siswa diperoleh rata-rata 14,28 pada rentang 14-16 dengan kriteria sangat baik. Dengan pengamatan pada hasil angket semua siswa sangat berperan aktif saat media digunakan. Berdasarkan hasil angket dapat disimpulkan bahwa media chem puzzle yang dihasilkan layak digunakan sebagai media pembelajaran. Chem puzzle yang dikembangkan ini dapat digunakan sebagai alternatif media pembelajaran kimia yang menarik khususnya pada materi tata nama senyawa.
\end{abstract}

Kata kunci: : Kimia, Tata Nama Senyawa, Penelitian Pengembangan, Media Chem Puzzle

Abstract. This study aims to test the feasibility of chem puzzles as a medium of learning on compound nomenclature in SMAN 1 Alalak. The research method was $R \& D$ (Research and Development) by Sugiyono steps 1 to 8 . The data analysis technique used by researchers was quantitative descriptive. The results of validity analysis of the chem puzzle media through questionnaire by experts obtained an average of 93.75 with a very feasible category. The questionnaire analysis result of the use of chem puzzle media on students obtained an average of 14.28 in the range of 14-16 with very good criteria. By observing the results of the questionnaire, all students played an active role when the media was used. Based on the results of the questionnaire, it can be concluded that the developed chem puzzle media is suitable for use as a learning medium. This chem puzzle can be used as interesting chemistry learning media especially for the nomenclature of compounds topic.

Keywords: Chemistry, Nomenclature of Compounds, Development Research, Chem Puzzle Media 


\section{PENDAHULUAN}

Tertatanya pendidikan yang baik dapat menciptakan generasi yang berkualitas (Artini dkk, 2019). Pendidikan merupakan suatu jembatan untuk membangun karakter dan juga mencerdaskan kehidupan bangsa dari satu genarasi ke generasi berikutnya melalui pengajaran, pelatihan dan penelitian. Pengembangan kurikulum 2013 merupakan salah satu upaya pemerintah dalam meningkatkan kualitas pendidikan. Melalui kurikulum 2013, diharapkan mampu meningkatkan kualitas pendidikan baik dari segi religius, sikap, pengetahuan dan keterampilan. Keempat kompetensi tersebut dapat ditanamkan melalui pembelajaran. Inovasi pembelajaran baik dalam hal strategi, pendekatan, metode, model maupun media pembelajaran dilakukan untuk meningkatkan kualitas proses pembelajaran (Widyawati dkk, 2016).

Pembelajaran adalah suatu proses interaksi, komunikasi atau penyampaian informasi yang disampaikan oleh seorang guru kepada siswa. Kata lain, pembelajaran dikatakan sebagai proses untuk membantu siswa dalam belajar. Pembelajaran yang diberikan oleh guru hendaknya dapat terjadi proses pemerolehan ilmu dan pengetahuan, penguasaan dan kemahiran, tabiat, serta pembentukan sikap dan kepercayaan pada siswa (Khairunnisa dkk, 2019).

Pada pembelajaran di sekolah tingkat SMA/MA, salah satu mata pelajaran yang dianggap sulit dipelajari adalah kimia. Menurut Ristiyani dkk (2016), materi pelajaran kimia di SMA/MA merupakan materi yang cukup sulit dipahami oleh siswa, karena banyak berisi konsep-konsep tentang reaksi-reaksi kimia dan hitungan-hitungan yang bersifat abstrak sehingga siswa menganggap materinya merupakan materi yang relatif baru. Kimia juga mempelajari komposisi dan sifat zat atau materi dari skala atom hingga molekul (Herawati dkk, 2018).

Berdasarkan hasil wawancara dengan seorang guru kimia di SMAN 1 Alalak ditemukan bahwa minimnya penggunaan media pembelajaran salah satunya pada materi tata nama senyawa, dalam pembelajaran sehari-hari hanya buku paket sehingga siswa kurang aktif dan kurang termotivasi dalam kegiatan belajar mengajar. Siswa yang aktif hanya beberapa saja baik dalam bertanya maupun menjawab pertanyaan. Guru telah berusaha mengajar dengan baik dan mudah tetapi masih saja ada sebagian siswa sering lupa sehingga pada saat pengulangan materi ataupun latihan soal masih ada siswa yang tidak bisa menjawab pertanyaan.

Salah satu cara untuk mengatasi sebuah kesulitan dalam menyampaikan materi yang sulit agar mudah diingat yaitu dengan menggunakan permainan. Dengan permainan, suasana belajar penuh ceria, semangat dan kelas akan menjadi lebih hidup. Selain itu, siswa akan menjadi pro aktif dan percaya diri mengikuti pelajaran. Diharapkan permainan dapat menjadi media yang bermanfaat sesuai dengan kondisi pembelajaran yang ada dengan cara membantu siswa untuk lebih paham akan materi yang dikemas seacara menyenangkan (Putri, 2018). Media pembelajaran merupakan sarana atau alat bantu yang dapat digunakan untuk menyalurkan pesan, perasaan, merangsang pikiran, perhatian dan kemauan peserta didik dapat terdorong dan terlibat dalam proses pembelajaran (Wisnarni dkk, 2018). Solusi yang dilakukan untuk mengatasi permasalahan ini peneliti mencoba untuk mengembangkan media pembelajaran sebagai alat bantu guru. Media yang dapat digunakan untuk menciptakan suasana pembelajaran yang menyenangkan dan memudahkan siswa untuk mengingat materi salah satunyaadalah media chem puzzle. Chem puzzle adalah media pembelajaran 
yang menugaskan siswa untuk menyusun potongan- potongan puzzle. Potonganpotongan puzzle tersebut berupa senyawa anion, senyawa kation, rumus senyawa dan nama senyawa disusun menjadi tata nama yang sempurna. Siswa diberi petunjuk berupa rumus senyawa ataupun nama senyawa lalu mereka mencari potongan anion dan kation yang cocok dengan rumus senyawa ataupun nama senyawa tersebut. Melalui media puzzle siswa akan lebih bersemangat dalam belajar sehingga dapat meningkatkan hasil belajar. Hal ini didukung oleh penelitian tentang chem puzzle oleh Kurniati (2016), menyatakan hasil penelitian menggunakan media chem puzzle efektif dan layak digunakan untuk media pembelajaran yang mampu meningkatkan semangat dan prestasi/hasil belajar siswa. Selain itu juga didukung oleh penelitian Armiati (2015) tentang puzzle, menyatakan media puzzle sangat berpengaruh terhadap aktivitas siswa. Pengembangan media chem puzzle diharapkan mampu menjadi alat bantu pembelajaran untuk siswa agar lebih aktif dalam mengikuti kegiatan pembelajaran sehingga dapat meningkatkan keaktifan siswa pada materi tata nama senyawa. Maka dari itu perlu dilakukan penelitian yang berjudul "Pengembangan Chem Puzzle Pada Materi Tata Nama Senyawa Kelas X di SMAN 1 Alalak".

\section{METODE PENELITIAN}

Tempat penelitian di SMAN 1 Alalak. Model pengembangan yang di gunakan adalah R \& D (Research \& Development) media chem puzzle menggunakan langkah 1-8 oleh Sugiyono (2016). Teknik pengumpulan data yang digunakan adalah teknik pengisian angket. Teknik pengisian angket digunakan untuk memperoleh data berupa (1) kelayakan media chem puzzle dari para validator, (2) respon siswa terhadap media chem puzzle dari subjek uji coba produk, (3) respon siswa terhadap pembelajaran menggunakan media chem puzzle dari subjek uji coba pemakaian produk. Pada teknik analisis data skor hasil validasi diukur menggunakan skala likert. Skala likert digunakan untuk mengukur kelayakan isi, kebahasaan, penyajian, dan kegrafisan. Instrumen yang digunakan dalam penelitian ini adalah: (1) angket kelayakan media yang terdiri dari unsur isi, bahasa, kegrafisan dan sajian, (2) angket respon siswa terhadap media chem puzzle, (3) angket respon siswa terhadap pembelajaran menggunakan media chem puzzle.

\section{HASIL PENELITIAN DAN PEMBAHASAN \\ Tahap potensi dan masalah}

Pada tahapan ini, didasari dengan adanya suatu potensi masalah bahwa ditemukan minimnya penggunaan media pembelajaran dalam pembelajaran kimia di SMAN 1 Alalak. Sehingga perlu dilakukannya pengembangan media pembelajaran untuk materi tata nama senyawa. Media yang dikembangkan berupa chem puzzle. Untuk menemukan potensi dan masalah ini dengan mewawancarai guru kimia di SMAN 1 Alalak.

\section{Tahap Pengumpulan Data}

Adapun analisis kebutuhan guna memperoleh data informasi sebagai pengumpulan data awal. Pengumpulan data ini melalui kajian literatur yang berkenaan dengan media pembelajaran yang akan dikembangkan meliputi: (1) teori-teori tentang media pembelajaran, (2) hasil-hasil penelitian yang relevan.Hasil pengumpulan data yang dilakukan adalah wawancara. Data yang diperoleh dari wawancara kepada guru yaitu minimnya penggunaan media pembelajaran di sekolah SMAN 1 Alalak. 


\section{Tahap Desain Produk}

Selanjutnya tahap pembuatan media. Adapun tujuan yang ingin dicapai dengan menggunakan media chem puzzle yaitu untuk membantu siswa dalam menjawab soal latihan pada saat pengulangan materi dengan mudah serta melatih kemampuan berfikir siswa. Waktu penelitian ini sudah direncanakan untuk tempat di SMAN 1 Alalak dan waktu penelitian.

Menurut Winanti dkk (2014) media puzzle adalah media permainan sederhana yang dimainkan dengan cara dibongkar dan dipasang kembali. Sebagai mana yang telah di desain oleh peneliti permainan dengan bongkar pasang dengan menyusun potongan kation, anion, rumus dan nama senyawa yang diletakan dibagian tengah puzzle dengan memerlukan bahan yang perlu digunakan untuk membuat chem puzzle seperti styrofoam, cutter untuk memotong styrofoam, kertas A4 dan lem untuk menempel kertas pada styrofoam. Hasil desain awal media chem puzzle ini dikonsultasikan kepada dosen pembimbing.

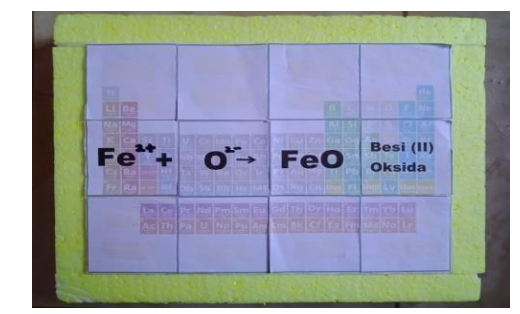

Gambar 1. Desain awal media chem puzzle

Adapun peraturan permainan media chem puzzle dibuat sebagai berikut.
a. Guru membagi siswa menjadi beberapa kelompok.
b. Kelompok dibentuk terdiri atas 3-4 orang.
c. Guru membagikan media chem puzzle kepada setiap kelompok.
d. Guru menyebutkan rumus senyawa ataupun nama senyawa kemudian meminta siswa untuk mencari pasangan unsur anion atau kation yang cocok sesuai dengan rumus ataupun nama senyawa tersebut.
e. Guru memberi waktu 3 menit untuk siswa menyusun puzzle tersebut.
f. Guru memeriksa jawaban siswa.
g. Dilakukan secara berulang.
h. Permainan berakhir sampai waktu yang ditentukan guru sudah habis.

\section{Tahap Validasi Desain Produk}

Menurut Masykur (2017), validasi desain adalah langkah untuk menilai apakah rancangan pengembangan produk, dalam hal ini sudah cukup dikatakan layak sebelum uji coba produk. Media chem puzzle pada materi tata nama senyawa divalidasi oleh 3 orang validator yang merupakan dosen pendidikan kimia serta guru mata pelajaran IPA. Saran dan komentar dari ahli media yaitu ukuran chem puzzle diperbesar, ukuran media terlalu kecil, gunakan kertas yang lebih tebal untuk puzzle dan warna SPU terlalu mencolok, ukuran puzzle sedikit diperbesar (F4), jumlah siswa dalam 1 kelompok 
maksimal 4 orang dan ukuran huruf diperbesar. Adapun rata-rata hasil validasi media chem puzzle oleh 3 orang validator pada setiap aspek penilaian sebagai berikut:

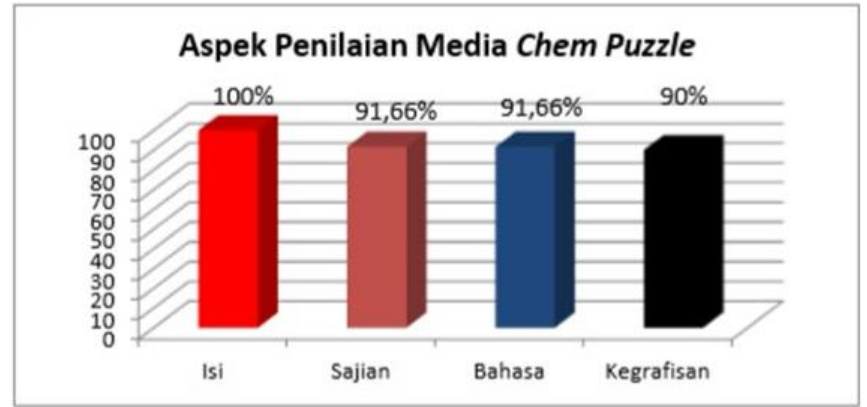

Gambar 2. Rata-rata hasil validasi media chem puzzle oleh 3 orang validator pada setiap aspek penilaian

Berdasarkan diagram di atas aspek penilaian media chem puzzle pada lembar validasi terdapat 4 aspek penilaian yaitu isi, sajian, bahasa dan kegrafisan. Rata-rata nilai pada aspek isi $100 \%$, bahasa dan kegrafisan memiliki persentase sebesar 91,66\%. Sedangkan pada aspek sajian memiliki persentase sebesar 90\%. Jadi, rata-rata keseluruhan setiap aspek penilaian media chem puzzle memiliki persentase sebesar 93,33\%. Berdasarkan validasi ditinjau dari ahli media sejumlah 3 orang validator diperoleh skor keseluruhan validator dengan rata-rata nilai sebagai berikut:

Tabel 1. Hasil uji kelayakan dari validator

\begin{tabular}{lccc}
\hline Validator & Nilai & Hasil & Kriteria \\
\hline Validator 1 & 29 & $90,62 \%$ & Sangat layak \\
Validator 2 & 32 & $100 \%$ & Sangat layak \\
Validator 3 & 29 & $90,62 \%$ & Sangat layak \\
\hline Rata-Rata & 30 & $93,75 \%$ & Sangat layak \\
\hline
\end{tabular}

\section{Tahap Revisi Desain}

Peneliti merevisi desain media chem puzzle setelah mendapatkan umpan balik dari validator sampai media tersebut dikategorikan layak. Berdasarkan saran dari validator cenderung media terlalu kecil, maka perlu diperbesar agar lebih mudah digunakan oleh siswa. 


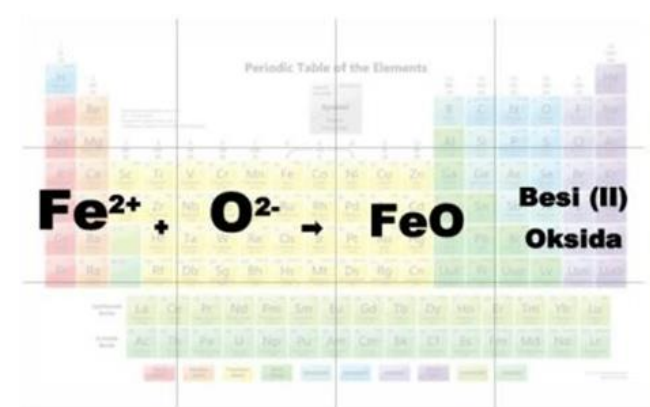

Gambar 3. Chem puzzle setelah direvisi

\section{Tahap Uji Coba Produk}

Pada tahap ini dilakukan uji coba terhadap produk pada siswa kelas XI IPA SMAN 1 Alalak untuk mengetahui respon siswa terhadap media chem puzzle pada materi tata nama senyawa. Sampel yang digunakan 16 orang siswa kelas XI IPA SMAN 1 Alalak. Berdasarkan hasil kelayakan media pada uji coba media chem puzzle diperoleh hasil dengan mayoritas kategori baik, sehingga dapat disimpulkan bahwa pengembangan media chem puzzle "baik" digunakan untuk pembelajaran. Nilai uji coba kelompok kecil diperoleh hasil rata-rata 16,67. Maka kategori nilai tersebut dinyatakan "baik".

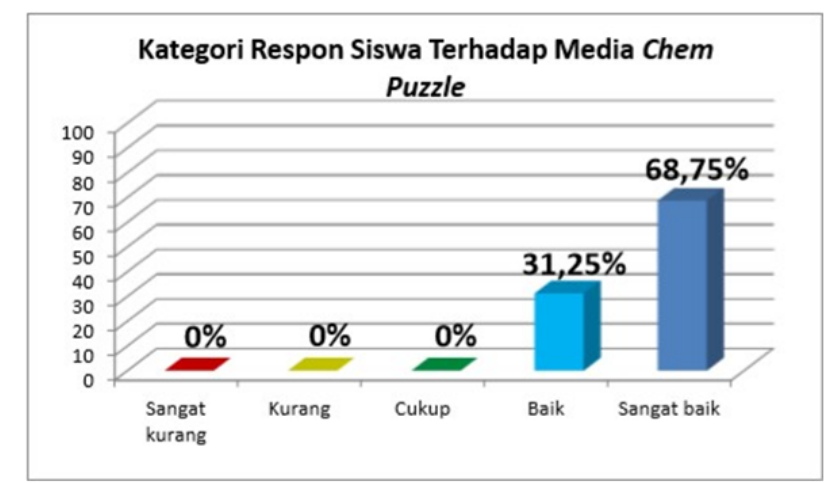

Gambar 4. Hasil rekapitulasi setiap item pernyataan angket respon siswa terhadap media chem puzzle

Adapun hasil rata-rata skor angket respon siswa yang diperoleh, 11 orang dengan rata-rata nilai sangat baik yaitu 17,54 dan 5 orang dengan rata-rata nilai baik yaitu 15,8. Sedangkan rata-rata keseluruhannya sebesar 16,67. Hal ini dapat dinyatakan pada uji coba produk memiliki nilai rata-rata nilai yang baik. 


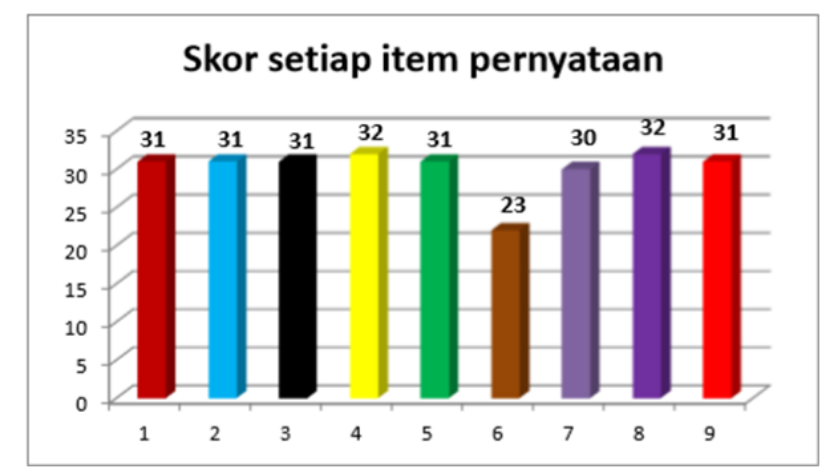

Gambar 5. Hasil rekapitulasi setiap item pernyataan angket respon siswa terhadap media chem puzzle

\section{Tahap Revisi Produk}

Peneliti revisi media chem puzzle yang dihasilkan setelah memperoleh umpan balik dari subjek uji coba produk yaitu 16 siswa kelas XI IPA di SMAN 1 Alalak. Saran dan komentar siswa cenderung bahwa warna background SPU media kurang cerah dan ukuran huruf tulisan kation, anion, rumus dan nama masih diperbesar lagi.

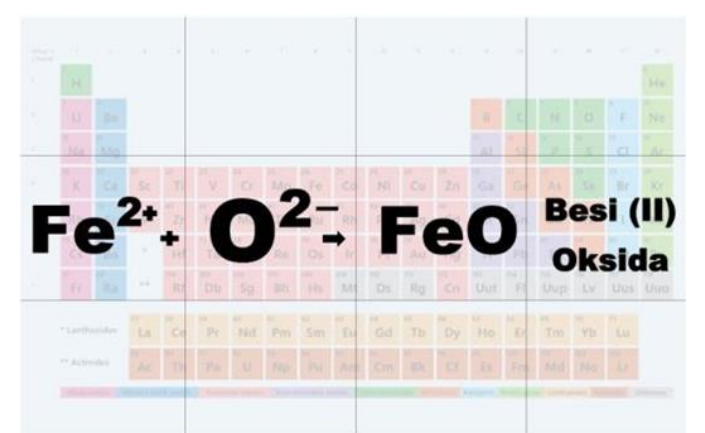

Gambar 6. Chem puzzle setelah direvisi dari uji coba produk

\section{Tahap Uji Pemakaian Produk}

Tahap ini dilakukan uji coba pemakaian produk pada siswa kelas X IPA SMAN 1 Alalak menggunakan media chem puzzle pada materi tata nama senyawa yang berjumlah 32 siswa. Penggunaan chem puzzle ini di gunakan setelah materi tata nama senyawa disampaikan di kelas. Pada pertemuan pertama dengan waktu 2 x 45 menit. Guru menyampaikan materi penamaan senyawa biner logam dan nonlogam yang akan dipelajari dan menyampaikan tujuan pembelajaran. Pada Tahap selanjutnya yaitu pelaksaan kegiatan inti dimulai dengan menyampaikan materi yang mana guru terlebih dahulu menyampaikan definisi dari tata nama senyawa. Lalu guru menjelaskan aturan penamaan senyawa biner logam dan nonlogam yang dilanjutkan dengan memberikan contoh. Setelah menyampaikan materi lalu guru memberikan latihan dengan menggunakan media chem puzzle. Sebelumnya guru menjelaskan terlebih dahulu tentang peraturan permainan. Siswa dibagi menjadi 8 kelompok yang mana setiap kelompok terdiri dari 4 orang siswa. Guru menyebutkan rumus senyawa atau nama senyawa lalu 
siswa mencari kation dan anion yang sesuai dengan rumus dan nama senyawa tersebut. Saat penggunaan media chem puzzle di kelas siswa sangat antusias dalam menggunakan media ini. Media yang digunakan dalam bentuk permainan membuat siswa lebih senang untuk belajar dan menjadi lebih aktif menjawab pertanyaan. Seperti yang dikatakan oleh Ginayah dkk (2018) media teka-teki silang kimia / crossword puzzle mengandung unsur permainan sehingga dapat menghilangkan rasa jenuh di kelas, membuat siswa jadi lebih aktif dan mengasah otak siswa.

Saat penggunaan media chem puzzle terjadi diskusi antar kelompok sehingga siswa menjadi aktif dalam kelompoknya. Penggunaan media ini juga merubah suasana kelas yang tadinya pasif menjadi aktif dan ramai di kelas. Selama ini di sekolah guru telah berusaha menjelaskan materi dengan menggunakan media buku paket tetapi saat guru menjelaskan materi siswa menjadi jenuh, kurang aktif sehingga pembelajaran terlihat monoton. Pada pertemuan pertama ini menggunakan media chem puzzle hanya 8 soal yang sempat dikerjakan karena keterbatasan waktu. Pada soal pertama dan kedua semua kelompok menjawab dengan benar, pada soal ketiga ada satu kelompok yang kurang tepat dalam menentukan muatan. Pada soal keempat, kelima, keenam, ketujuh semua jawaban kelompok siswa benar dan soal kedelapan ada satu kelompok siswa lagi yang kurang tepat dalam menentukan angka indeks. Tahap selanjutnya setelah menggunakan media chem puzzle guru memberi soal evaluasi kepada siswa. Guru menutup pembelajaran bersama siswa dan mengakhiri pembelajaran dengan mengucapkan salam.

Pertemuan kedua dengan waktu 1 x 45 menit, materi yang disampaikan yaitu penamaan senyawa poliatomik. Sebelumnya guru menyampaikan tujuan pembelajaran kemudian menyampaikan definisi poliatomik dan memberikan contoh aturan penamaan poliatomik. Selanjutnya latihan soal menggunakan media chem puzzle sama pertemuan pertama siswa dibagi lagi menjadi 8 kelompok. Pada pertemuan kedua ini 7 soal yang sempat dikerjakan. Rata-rata kelompok siswa benar dalam menjawab soal, hanya saja pada soal kelima ada satu kelompok siswa yang kurang tepat dalam menentukan nama senyawa tersebut. Pada pertemuan kedua ini mengalami peningkatan dari pertemuan pertama karena hanya satu soal yang tidak benar dijawab oleh satu kelompok siswa. Terakhir guru memberikan soal evaluasi kepada siswa. Guru menutup pembelajaran bersama siswa dan mengakhiri pembelajaran dengan mengucapkan salam.

Pada pertemuan ketiga dengan waktu 2 x 45 menit, materi yang disampaikan yaitu penamaan senyawa asam dan basa. Pada pertemuan ini dilakukan sama seperti pertemuan pertama dan kedua. Pada saat latihan soal menggunakan media chem puzzle, soal yang diberikan hanya sempat 6 soal karena keterbatasan waktu. Pada latihan ini semua kelompok siswa benar dalam menjawab soal, itu berarti pada pertemuan ini sangat mengalami peningkatan. Kemudian guru memberikan evaluasi pembelajaran kepada siswa. Saat pertemuan ketiga guru memberikan angket uji kelayakan media kepada siswa setelah pembelajaran selesai. Tahap melihat respon siswa saat menggunakan media chem puzzle layak di gunakan atau tidak. Untuk mengetahui respon siswa di beri angket kelayakan media yang telah dirancak oleh peneliti dan sudah di konsulkan dengan dosen pembimbing.

Jumlah siswa pada kelas X IPA ini adalah 32 orang. Saat pengisian angket ada 2 orang tanpa keterangan dan 2 orang siswa yang tidak hadir karena sakit. Jadi, jumlah siswa yang tersisa mengisi angket sebanyak 28 orang. Angket uji kelayakan media chem 
puzzle di validasi oleh 3 validator yaitu 1 dosen dan 2 guru. Angket ini dibuat sendiri oleh peneliti dan sudah dikonsultasikan kepada dosen pembimbing. Pengisian angket di lakukan saat penelitian terakhir. Produk ini digunakan setelah materi di jelaskan oleh guru. Adapun hasil uji media chem puzzle pada materi tata nama senyawa adalah sebagai berikut :

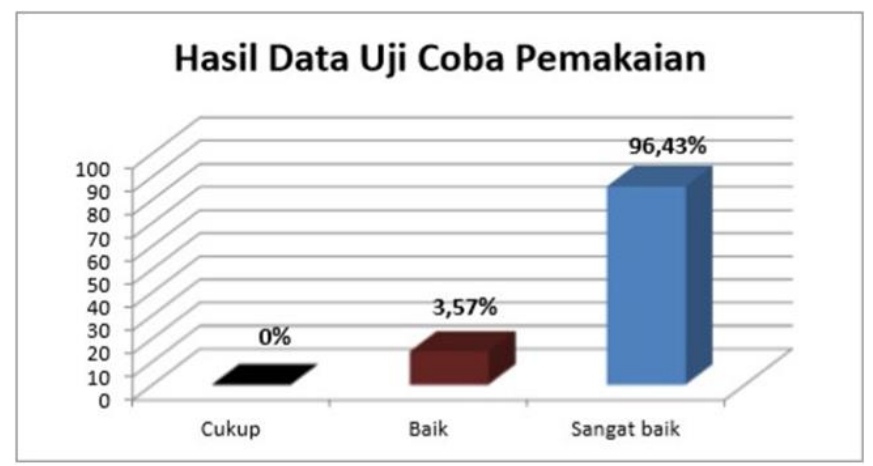

Gambar 7. Persentase hasil data uji coba pemakaian media chem puzzle

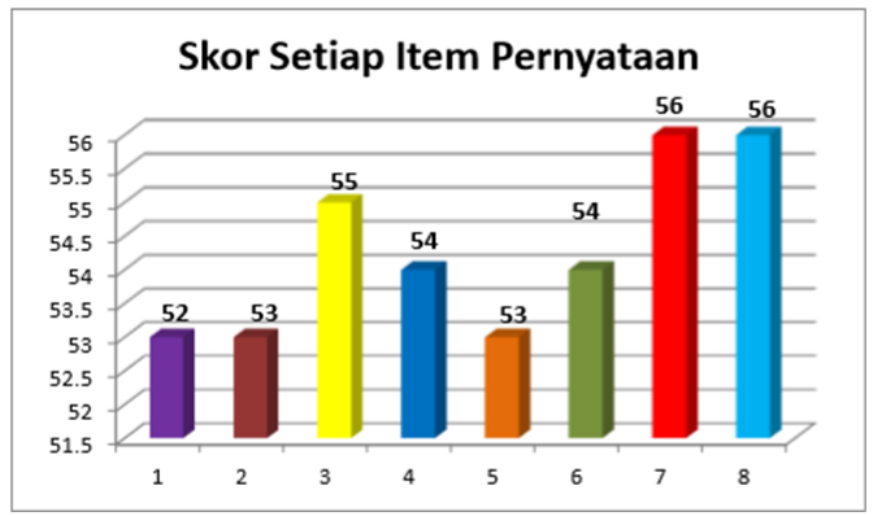

Gambar 8. Hasil rekapitulasi setiap item pernyataan angket respon siswa pada kelompok besar terhadap media chem puzzle

Berdasarkan skor setiap item pernyataan Angket respon siswa memiliki 8 pernyataan dengan aspek penilaian 2 alternative jawaban 1 dan 2 yaitu : setuju $=2$, tidak setuju $=1$. Total skor tertinggi mencapai 56 ditunjukan pada pernyataan 7 dan 8 yang mana jumlah skor ini adalah skor maksimal. Pada pernyataan 1 menunjukan skor 52, ,pernyataan 2 dan 5 menunjukan total skor yang sama yaitu 53. Pernyataan 3, 4, 6 memperoleh total skor yang tidak jauh berbeda dengan skor berturut-turut 55, 54, 54 . Jadi, rata-rata skor keseluruhan respon siswa setiap pernyataan sebesar 54,12.

Dari hasil respon siswa diperoleh data dengan rata-rata 14,28 yang diperoleh pada tabel penentuan kriteria berada pada rentang 14-16 sehingga termasuk kriteria "sangat baik". Berdasarkan perolehan data tersebut dapat disimpulkan bahwa media pembelajaran yang dikembangkan layak digunakan untuk siswa yang kurang 
bersemangat saat pengulangan materi dalam materi tata nama senyawa. Pada evaluation ini tidak ada revisi dari siswa. Siswa menganggap media ini layak digunakan dan menarik saat digunakan. Hal ini terbukti dari penelitian pengembangan media puzzle oleh Husna dkk (2016) bahwa media puzzle layak digunakan sebagai media pembelajaran.

\section{SIMPULAN}

Berdasarkan hasil penelitian, analisis dan pembahasan maka dapat diambil kesimpulan bahwa media pembelajaran yang dikembangkan berupa chem puzzle sangat layak digunakan pada materi tata nama senyawa kelas X.

\section{DAFTAR RUJUKAN}

Armiati, S. E \& Pahriah. (2015). Pengaruh Model Somatic Auditory Visualization Intellectualy (SAVI) Dengan Media Puzzle Terhadap Aktivitas dan Pemahaman Konsep Siswa Pada Materi Hidrokarbon. Hydrogen : Jurnal Kependidikan Kimia, 3(2), 302-308.

Artini, D., Suardana, N \& Wiratini, M. (2019). Pengaruh Model Pembelajaran Kontekstual Pada Pokok Bahasan Hidrokarbon Terhadap Hasil Belajar Kimia. Jurnal Pendidikan Kimia Undiksha, 3(1), 20-28.

Ginayah, L. U., Mashuri, M. T \& Wardhani, R. R. A. K. (2018). Pengaruh Media Tekateki Silang (TTS) Kimia 3D Terhadap Kemampuan Kreatif Siswa Pada Materi Hidrokarbon Kelas X SMA Negeri 12 Banjarmasin. Dalton : Jurnal Pendidikan Kimia dan Ilmu Kimia, 1(2), 14-19.

Herawati, N. S \& Muhtadi, A. (2018). Pengembangan Modul Elektronik (E-Modul) Interaktif Pada Materi Pelajaran Kimia Kelas XI SMA. Jurnal Inovasi Teknologi Pendidikan, 5(2), 180-191.

Husna, N., Sari, S. A \& Halim, A. (2017). Pengembangan Media Puzzle Materi Pencemaran Lingkungan di SMP Negeri 4 Banda Aceh. Jurnal Pendidikan Sains Indonesia, 5(1), 66-71.

Khairunnisa, U., Akhyar, O \& Wardhani, R. A. A. K. (2019). Pengembangan Media Wheels Question Pada Materi Sistem Koloid Untuk Meningkatkan Motivasi Belajar Siswa Kelas XI di SMA Negeri 12 Banjarmasin. Dalton: Jurnal Pendidikan Kimia dan Ilmu Kimia, 2(1), 22- 27.

Kurniati, S., Erviyenni \& Azmi, J. (2015). Penggunaan Media Chem Puzzle Untuk Meningkatkan Prestasi Belajar Siswa Pada Pokok Bahasan Hidrokarbon di Kelas X SMA Negeri 4 Pekanbaru. Jurnal Online Mahasiswa Fakultas Keguruan dan Ilmu Pendidikan, 3(1), 1-11.

Masykur, R., Nofrizal \& Syazali, M. (2017). Pengembangan Media Pembelajaran Matematika dengan Macro Media Flash. Al-Jabar: Jurnal Pendidikan Matematika. .8(2), 177-186.

Putri, R, H. 2018. Pengembangan Media Triangle Bomb-R Materi Pokok Ukuran Bidang Pandang Pengambilan Gambar PadaMata Pelajaran Komposisi Foto Digital Kelas XI Multimedia SKMN 10 Surabaya. Jurnal Mahasiswa Teknologi Pendidikan. 9(2), 1-4. 
Dalton : Jurnal Pendidikan Kimia dan Ilmu Kimia, Volume 4 Nomor 2, November 2021

Ristiyani, E \& Bahriah, E. S. (2016). Analisis Kesulitan Belajar Kimia Siswa di SMAN X Kota Tangerang Selatan. Jurnal Penlitian dan Pembelajaran IPA. 2(1), 1829.

Sudjana, N. 2013. Dasar-dasar Proses Belajar Mengajar. Bandung: Sinar Baru Algensindo.

Sugiyono. (2016). Metode Penelitian Pendidikan Pendekatan Kuantitatif, Kualitatif dan $R \& D$. Bandung : Alfabeta, cv.

Widyawati, R. L., Utomo, S \& B., Saputro, S. (2016). Penerapan Model Pembelajaran Teams Games Tournaments (TGT) Dilengkapi Flash Chemquiz Untuk Meningkatkan Minat dan Prestasi Belajar Materi Hidrokarbon Pada Siswa Kelas X-8 SMA Negeri 3 Boyolali Tahun Pelajaran 2015/2016. Jurnal Pendidikan Kimia (JPK), 5(4), 75-82.

Winanti, S., Sungkono \& Hardianto, D. (2015). Pengembangan Media Puzzle Rantai Makanan Untuk Mata Pelajaran Ilmu Pengetahuan Alam SD. E-Jurnal Skripsi Program Studi Teknologi Pendidikan.

Wisnarni J, E., Erviyenni \& Haryati, S. 2018. Pengembangan Berbasis Powtoon Pada Pokok Bahasan Koloid di SMA/MA. Jurnal Civics : Media Kerajinan Kewarganegaraan. 15(1), 1-10. 